\title{
Politeness Strategies of Metaphorical Expression in Tegalan Short Stories
}

\author{
Rahayu Pristiwati ${ }^{1}$, Rustono ${ }^{2}$, and Dyah Prabaningrum ${ }^{3}$ \\ \{pristi@mail.unnes.ac.id ${ }^{1}$,pr1@mail.unnes.ac.id ${ }^{2}$, dyahprabaningrum@mail.unnes.ac.id ${ }^{3}$ \} \\ Universitas Negeri Semarang, Kampus Sekaran, FBS, Deparment of BSI, Semarang 50229, Indonesia.
}

\begin{abstract}
At this time, the younger generation behaviour nowadays which is not appreciative of others. The appreciation for others is a characteristic of Javanese people in social interaction. Tegalan Java Ethnic is one of the Javanese ethnics that has blakasuta or telling the truth is commonly found in Tegal community. In this paper, the authors analyze the politeness metaphorical expression strategy in the Tegalan Java ethnic short story. It aims to describe the metaphorical expression that can be used as a strategy to speak politely in the reality of society. This study is qualitative descriptive research. The data analysis method uses a referential equivalent method. This research has been able to collect politeness metaphorical expressions of Tegalan Java ethnic namely pramupijet that refers to the plus-plus masseuse, dikurangajari as a call when they are being asked to serve biological needs, etc.
\end{abstract}

Keywords: politeness, metaphorical expression, cerdek of Tegalan Java ethnic.

\section{Introduction}

The values of life which are held by the people have shifted. Formerly Javanese knew manners (unggah-ungguh). With the complexity of the language that is owned and the level of language in it, it is not unusual for every social stratum to have rules in expressing things. However, in line with the development of the times, values filled with rules of social strata eroded and replaced with egalitarian values. Therefore, Indonesian, which has a simple level, slowly replaces regional languages that have many levels. The way someone talks, including the language which is used, changes. Some people choose to say something vulgarly without the language of the connotation that is softening the speech that is said. The effect is not to give awareness or to get the desired information but to give offence so that the intention of communication is not achieved. In relation to this notion, studying metaphors contained in important literary works would be an example of a language strategy.

Metaphor is a very interesting thing in semantics (the science of meaning language). [1] put forward three concepts in the study of this field. The three concepts are (1) metaphor has an important meaning as a creative power in language, (2) metaphor has a very simple basic structure, and (3) metaphor as a tool to fill the void in vocabulary. The metaphorical expression is not something empty. It contains the purpose of communication. The creation of the metaphorical expression is based on a purpose. In conveying his intentions, writers often use metaphorical expressions. The use of metaphors in literary texts shows that metaphorical expressions really exist, they have been used, and they are understood in everyday Indonesian society. Additionally, [2]states that metaphors can penetrate in everyday life not only through 
language but also in thoughts and actions. In addition to expressions, metaphors can also be reflected in the choice of attitude. According to[3], the comparison between actions is a metaphor which has to mean as "action" of lexical and action meaning and also its metaphorical extension. It means that one's actions can be used as a reference to form a metaphor for both lexical and semantic metaphors. In relation to this, the phenomenon of the associative strategy in metaphorical expression as part of community activities reflected in its use in literary works becomes interesting to study. Literature is the result of the author's contemplation of reality as a representative mirror of the author's environment. One product of literary works is short stories. Short stories are literary works in the form of narrative prose. Events in short stories are brief, solid, with story ideas centred on one character and can be read in one reading.

Short stories, in this case, are not just entertainment; Moreover, short stories become an alternative media of education. Education is a conscious effort carried out by family, society and government through guidance, teaching and training that takes place in schools and outside schools to prepare students to be able to adapt in various environments [4]. Alternative education through reading and reviewing the main literary works of short stories is very possible for someone to feel happy in their learning. The problem statement in this paper is about the politeness strategy in metaphorical expressions in short stories of Tegalan Javanese ethnicity. The study aims to describe the metaphorical expression that can be used as a strategy to speak politely in the reality of society reflected in literary works, especially short stories of Javanese ethnicity.

Politeness according to Leech [5] divides politeness principles into six maxims/thimbles, namely (1) tact maxim, (2) generosity maxim, (3) approbation maxim, (4) modesty maxim, (5) agreement maxim, and (6) sympathy maxim. Questioning politeness, direct speech acts in which there are words of help, forgiveness, and gratitude are linguistic politeness, while politeness which is an implied expression to refine meaning is pragmatic politeness. In relation to that, measurement of politeness for Leech in [6] to measure politeness is at least three ways, namely the scale of profit costs, the scale of option, and scale of indirectness. In the scale of profit costs, there is a premise that the greater the speaker gives benefits to speech partner, the more polite the speech will be. The two scales of option in speech, the more the speaker gives choice to the speech partner, the more polite the speech will be. Three, the scale of indirectness states that the more indirect, the more polite.

Many studies related to politeness have been done but research on politeness in literature is still rare. Some of the researches on politeness were found in literary works are [7], [8], [9], [10]. The similarity between the present study and the previous studies is that they all examine the politeness of language in a literary work. The difference lies in the object of the research study. Different study objects will give different results for scientific contributions. This study employs the Tegalan ethnic short stories written by Tegal $\mathrm{M}$ and Hadi Utomo as the object of the study and it is in Tegal Javanese language.

\section{Method}

This study employed a qualitative approach. The qualitative aspect of this research was related to the data of this study which were not in the form of numbers but in the form of the quality of verbal forms which were tangible [11]. The research data were in the form of metaphorical expression strategies in short stories of Javanese ethnicity. The form of the data was text fragments and discourses of metaphorical expressions in the short stories of the 
Javanese ethnicity. The method of data analysis was a referential equivalent method. According to [12], in the equivalent method, the determinant is outside, is detached, and is not part of the language (langue) concerned. The method is used because the things studied in this study are the structure of the short story text by M. Hadi Utomo entitled 'Mata' and 'Waslam'. The basic technique used is the technique of determining the determinant elements by powering them to differentiate the referents. According to [12], the types of determinants will be separated or divided into various elements, the power of the sort is called the referential sorting power. Referential sorting power is used to determine the structure and variation of text structure in short stories that show the metaphor of politeness and fulfil the superstructure.

\section{Results and Discussion}

Short stories entitled 'Mata' and 'Waslam' are short stories written by native Tegal writers named M. Hadi Utomo. The short story "Mata" tells the story of a person who has just been appointed as the promoter of the insect repellent promotion company. He made his first official trip to an S city and stayed at a hotel called MS. According to stories from his friends, at the hotel, there is a masseuse who is although blind but beautiful. The masseuse can also provide more services. He was named Asih. Therefore, when Mr Karmo (the enforcer/figure in the story) made an official trip, he was curious to want to meet the masseuse. He met the masseuse and got a massage. It was the first time he got a massage from a woman other than his wife. When Asih massaged, a conversation happened. In the conversation, there are several texts and contexts which are metaphors of modesty. Even at the end of the story, the attitude written also shows politeness. The following are texts and discourses that show politeness.

The second short story entitled "Waslam" tells the story of crazy people who are nostalgic and hallucinating when they are at the top of the Monas. Waslam is said to have a younger brother. He experienced a hard life. Waslam said that he went up on the Monas and shouted explaining that he also asked his sister. In his hallucinations, Waslam saw his sister as a maid chatting with him. Meanwhile, the crowd below him admired him. Even though the truth is beneath the Monas, people are gossiping about it. Finally, Waslam was forcibly picked up using a helicopter by the army.

Here is the term or context which is a discourse/text related to the politeness strategy of the metaphorical expression in the short story of Tegalan Javanese ethnicity. In the short story entitled "Mata", Mr Karno and friends did not mention Asih with a rude term, such as PSK, prostitutes, complacency, or any other. They call Asih as pramupijet. Speech in the short story that shows the meteor is as follows.

"Rugi angger nginep nang MS ora ketemu Mbak

Asih", Mustarip ngomong maning karo ngedhe'p-ngedhe'pna mata kiwane'.

"Mbak Asih sapa?" aku penasaran.

“Mbak Asih kuwe' pramupijet nang Hotel MS", Pak Jenal nerangna karo setengahwisikan. "Senajan wonge' ora prawasan atawa tunanetra, tapi.... whuih. Kulite' putih, bodine'mulus, terus mijete' luar biasa [13]

The word pramupijet is like the word pramusaji and pramuniaga to soften an expression. The word pramusaji is to soften the word pelayan, the word pramuniaga is to soften the word karyawan/penjaga toko. The word pramupijet to soften the expression pijet plus-plus. The word pramupijet is a form of maximum appreciation. At least, the word pramupijet is different from prostitutes or PSKs. There is a tribute to a profession, or to earn money, pramupijet needs to 
master massaging skills. Pramupijet does not offer herself. She does her job, though she does not refuse to have an additional role. Therefore, not calling her PSK, prostitutes or complacent is politeness of maximum appreciation. The scale of politeness used is the scale of politeness by maximizing the cost of profit. The next speech which is a discourse of politeness is the choice of diction revealed by Mr Karno and Asih in his conversation when Asih was massaged.

Karo pijet aku iseng-iseng takon apa dhe'we'ke' sokan dikurangajari daning wong lanang sing dipijeti.

'Nggih namine' tiyang jaler. Wonten mawon ingkang nakal. Nanging ugi kathah kok piyantun ingkang sae'. Kados ingkang saweg pijet niki”, Mbak Asih njawab karo gemuyu [13].

Mr Karno used diction dikurangajari and did not use vulgar diction which directly mentioned sexual diction. Likewise, Asih picked diction nakal. The diction selection is a form of politeness because it maximizes the maxim of sympathy. Both of them carefully chose words to keep others from being offended. In addition, Asih's answer to compliment the client is a polite way of replying to show appreciation by saying there are still a lot of good men, for example, the man I am massaging. The scale of politeness used is a politeness scale that maximizes profit costs. The politeness of the attitude was shown by Mr Karno when Mr Karno knew from the story of Asih that Mr Jenal was lying. From the story of Asih, Asih also used the maxim of appreciation by praising the client, Mr Jenal who is in her thought.

"Lho Pak Jenal kan dhudho. Dados nggih sok aleman". Edan, aku ngomomg nang ati. Jebule' Pak Jenal ngakune' dhudha. "Pak Jenal anggere' mbayar royal sanget. Nanging menawi bibar pijet nyuwun bonus"[13].

Mr Karno knew that Mr Jenal had lied to Asih. But Mr Karno refrained from revealing the truth. The attitude taken by Mr Karno is a wise attitude. He restricts himself from interfering with the affairs of others, but knowingly. Mr Karno's attitude has shown that he uses the maxim of wisdom/wisdom. Indirectly, the scale used for this decency is an optional scale. By just letting Asih talk without being criticized/cut, Mr Karno has let someone who is being told and the storyteller chooses their choice of attitude to perceive or be perceived.

The next sentence that shows politeness is the word bonus and the word gantenan pijet.

"Bonus?. Bonus apa Mbak?"

"Nggih bonuse' werni-werni...he'he'he'...”Mbak Asih pesam-pe'sem. Angger Mustarip, sing ngakune' tesih bujang arane' Hendro, jare' angger bar dipijet njaluke' gente'nan mijet. Embuh maksude' apa. Ya, nang kamar hotel mung wong loroan thok, apa bae' bisa kedadian [13].

The word bonus and the word gantenan pijet is a softened diction from a wide variety of "biological services". The word refers to the maxim of the deal because the action took place with the agreement of two parties. Therefore, in the story, it is best for both parties to avoid rough language. The scale of politeness of that sentence is the scale of indirectness.

The other politeness is seen in the sentence which is a reminder of Asih's apology to Mr Karmo. Asih apologized sincerely and admitted her pretending acts of blindness.

"Pak Karmo, kulo nyuwun pangapunten. Kulo sampun nggorohi panjenengan lan tiyang-tiyang sanes" Mbak Asih ngomong lirih, matane' ngruwice'h arep nangis [13]

Asih's attitude shows the maxim of humility. Love is humble to apologize and admit her wrong deed. When asked, Asih also explained to Mr Karmo that he actually did so to earn a living and for the expenses of his son's operation. It appears in the following speech.

Nyuwun tulung Pak.... panjenengan sampun ngendiko sinten-sinten... kulo ethok-ethok wuto... supados saged mijet wonten hotel...’[13]

The word nyuwun tulung, nyuwun pangapunten is a form of linguistic politeness. Furthermore, the attitude shown by Pak Karno shows pragmatic politeness. 
Karo rasa trenyuh sing ora kira-kira aku ngrogoh dompet, ngetokna diwit atusan e'wu, terus tak kepelna nang tangan mungil anake' Mbak Asih. Mbak Asih ndremimil ngucapna trimakasih karo mingseg-migseg. Aku cepet-cepet pamit.[13]

The speech implies Pak Karno's understanding of Asih's attitude. Understanding of compassion is not reflected in words but with good luck and giving money to Asih's children. What Pak Karno does is the maxim of philanthropy with a scale of politeness that is a scale of profit. As in the short story entitled 'Waslam', researchers did not find much text referring to politeness. The form of politeness in the short story 'Waslam' was Waslam's advice for his sister in the hallucinations of Waslam. Here is the quote.

“Mbokan majikane' kowen mblunat, kowen lapor maring aku ya? Awas...

anggere majikane' kowen cluthak. Sing penting angger majikan wadone' kowen ora nang umah, terus majikan lanange' kowen dhe'we'kan, kowen kudu ngatiati..".

"Iya kang Waslam, aku ngati..."

“Terus angger bengi kowen lagi turu, aja klale'n lawange’ dikancing.

Mbokan ana sing nothok-nothok lawang, poma aja dibuka"

"Iya Kang”[14]

The advice is a form of someone's love. If it is classified into maxims, the politeness is more on the maxim of sympathy. Waslam who is ready to defend his younger brother when something happens can be included in the scale of profitability politeness.

\section{Conclusion}

From the analysis of the short story of Tegal's original literary work by M. Hadi Utomo entitled 'Mata' and 'Waslam', it can be concluded that there is politeness with maximal rewards, maxims of wisdom, and maxims of sympathy. Maksim is in the form of speech or deeds in a linguistic and pragmatic manner. The scale of politeness found in the two short stories above is the scale of profit costs, optional scale, and the scale of indirectness. From the short story above, increasingly using indirect speech is more polite and better.

Acknowledgments. We thank you to the organizers who organized ISET 2019. In addition, we thank for cultural critical of Tegal. 


\section{References}

[1] Ullman S. Semantics. Blackwell: Oxford; (1972).

[2] Lakoff G, Johnson M. Metaphors We Live By. London: University of Chicago Press; (2003).

[3] Pristiwati R, dkk. Metaphorical Meanings Inside of Discourse of President, Parliament, and Major National Election 2014. J Educ Dev. 2016;4(2):167-74.

[4] Ruhimat T. Kurikulum dan Pembelajaran. Jakarta: Graha Bandung Kencana; (2011).

[5] Zulaeha I, dkk. Bahasa Indonesia Pengantar Penulisan Karya Ilmiah. Semarang. Semarang: UNNES Press; (2019)

[6] Rustono. Pokok-Pokok Pragmatik. Semarang: IKIP Semarang Press; (1999).

[7] Alviah I. Kesantunan Berbahasa dalam Tuturan Novel Para Priyayi Karya Umar Kayam. Seloka J Pendidik Bhs dan Sastra Indones. 2014;3(2):128-135.

[8] Harahap SK. Analisis Pragmatik Kesantunan Berbahasa Novel Ngah Lara Karya Adi Mujabir. UMSU Medan; (2018).

[9] Kurniawan H. Analisis Kesantunan Berbahasa dalam Naskah Drama 'Ar Fakhruddin. UMS; (2018).

[10] Suyanto E. J-Simbol (Bahasa, Sastra, dan Pembelajarannya) Maret (2019);

[11] Muhadjir N. Metodologi Penelitian Kualitatif. Yogyakarta: Rake Sarasin; (1996).

[12] Sudaryanto. Metode dan Teknik Analisis Bahasa. Yogyakarta: Duta Wacana Universitas Press; (2015).

[13] Utomo MH. Mata. In Dokumentasi Cerpen Tegal; (2019)

[14] Utomo MH. Waslam. In CerpenTegalan dokumentasi penelitian; (2019). 